\title{
Optimalisasi Penggunaan Website Kabupaten Pandeglang untuk Penyebaran Informasi Publik
}

\author{
Ika Nurlaili Isnainiyah ${ }^{1, *}$, lin Ernawati ${ }^{1}$ \\ ${ }^{1}$ Fakultas IImu Komputer; Universitas Pembangunan Nasional Veteran Jakarta; Jl. RS. \\ Fatmawati Raya No. 1, Pondok Labu, Cilandak, Jakarta Selatan, DKI Jakarta, (021) 7656971; \\ e-mail: nurlailika@upnvi.ac.id, iinernawati@upnvi.ac.id \\ * Korespondensi: e-mail: nurlailika@upnvj.ac.id
}

\begin{abstract}
The application of ICT to support government activities is known as e-government. The website is one of the technologies that has an important role in government institutions to facilitate digital relations between government and society. The implementation of the website acts as an information portal and supports policies regarding public information disclosure. This community service activity with the theme of optimizing digital content was carried out in the Smart Room at the Pandeglang Regency Diskomsantik office and was attended by employees who manage the Pandeglang Regency official website. This activity applies training and evaluation methods to sample case analysis. The results of the training activities showed an increase in knowledge of $24 \%$ related to case studies on website content.
\end{abstract}

Keywords: E-Government, Government, Optimalization, Public Information, Website

\begin{abstract}
Abstrak
Penerapan TIK untuk mendukung berbagai kegiatan pemerintahan dikenal dengan egovernment. Situs web adalah bentuk teknologi yang memiliki peran penting dalam institusi pemerintahan untuk memfasilitasi hubungan pemerintah dengan masyarakat yang dilakukan secara digital. Penerapan website juga berperan sebagai sarana portal informasi dan mendukung kebijakan mengenai keterbukaan informasi publik. Pelaksanaan PkM ini telah diselenggarakan di Ruang Pintar, Diskomsantik Kabupaten Pandeglang dan ditujukan kepada pengelola website resmi Pemerintah Kabupaten Pandeglang mengenai tema optimalisasi konten. Metode pelaksanaan dilakukan dengan pelatihan dan hasil evaluasi terhadap analisa kasus. Hasil kegiatan pelatihan menunjukkan peningkatan pengetahuan sebesar $24 \%$ berkaitan dengan studi kasus pada konten situs web.
\end{abstract}

Kata kunci: E-Government, Pemerintah, Optimalisasi, Informasi Public, Website

\section{Pendahuluan}

Menyikapi era teknologi basis 4.0 saat ini, keberadaan situs web atau website telah secara luas dimanfaatkan sebagai media promosi dan pemasaran produk lokal, media penyebaran informasi dan edukasi masyarakat, maupun sebagai media untuk menyampaikan laporan, usulan serta kritik (Wiratmo, Irfan, \& Kuwantono, 2017). Dalam hal tata kelola pemerintahan, situs web memiliki fungsi strategis sebagai perangkat yang mendukung jalannya aktivitas pemerintahan dimana keberadaannya berperan dalam hubungan dengan masyarakat secara digital (Cahyana \& Zakaria, 2016). Hal tersebut dikarenakan situs web merupakan suatu 
jalur komunikasi efektif dalam menyebarkan informasi pada masyarakat secara luas melalui internet. Penerapan situs web juga sejalan dengan kebutuhan masyarakat untuk mengetahui aktivitas maupun kebijakan pemerintah yang didukung dengan diterapkannya Undang-Undang Nomor 14 tahun 2008 berkaitan dengan Keterbukaan Informasi Publik (Kamaliah, 2015).

Penerapan TIK untuk mendukung pemerintahan di Indonesia atau secara luas dikenal dengan e-government diawali dengan munculnya Inpres Nomor 3 Tahun 2003 (Sinaga, Suwitri \& Mustam, 2014). Dalam Inpres tersebut, ditekankan mengenai peran penting penerapan teknologi pada organisasi pemerintah untuk menciptakan proses tata kelola pemerintahan secara efektif serta efisien. Kehadiran e-government diharapkan mampu membuat birokrasi yang lebih terbuka serta memberikan kesempatan berbagai lembaga pemerintah untuk bersinergi dalam penyederhanaan akses informasi serta layanan baik pada organisasi pemerintah pusat maupun daerah (Yunita \& Aprianto, 2018).

Merujuk pada Inpres tersebut, untuk memulai penerapan suatu e-government maka langkah awalnya yaitu mencanangkan pembangunan website pada instansi pemerintahan. Pembanguna web akan difungsikan sebagai sarana portal informasi untuk memberikan publik informasi berkaitan dengan tugas maupun fungsi sebuah instansi.

Dalam implementasi e-government, terdapat empat tahap model kematangan egovernment dari Gartner Group (Lusta \& Aktas, 2017) yang dapat dilihat pada Gambar 1.

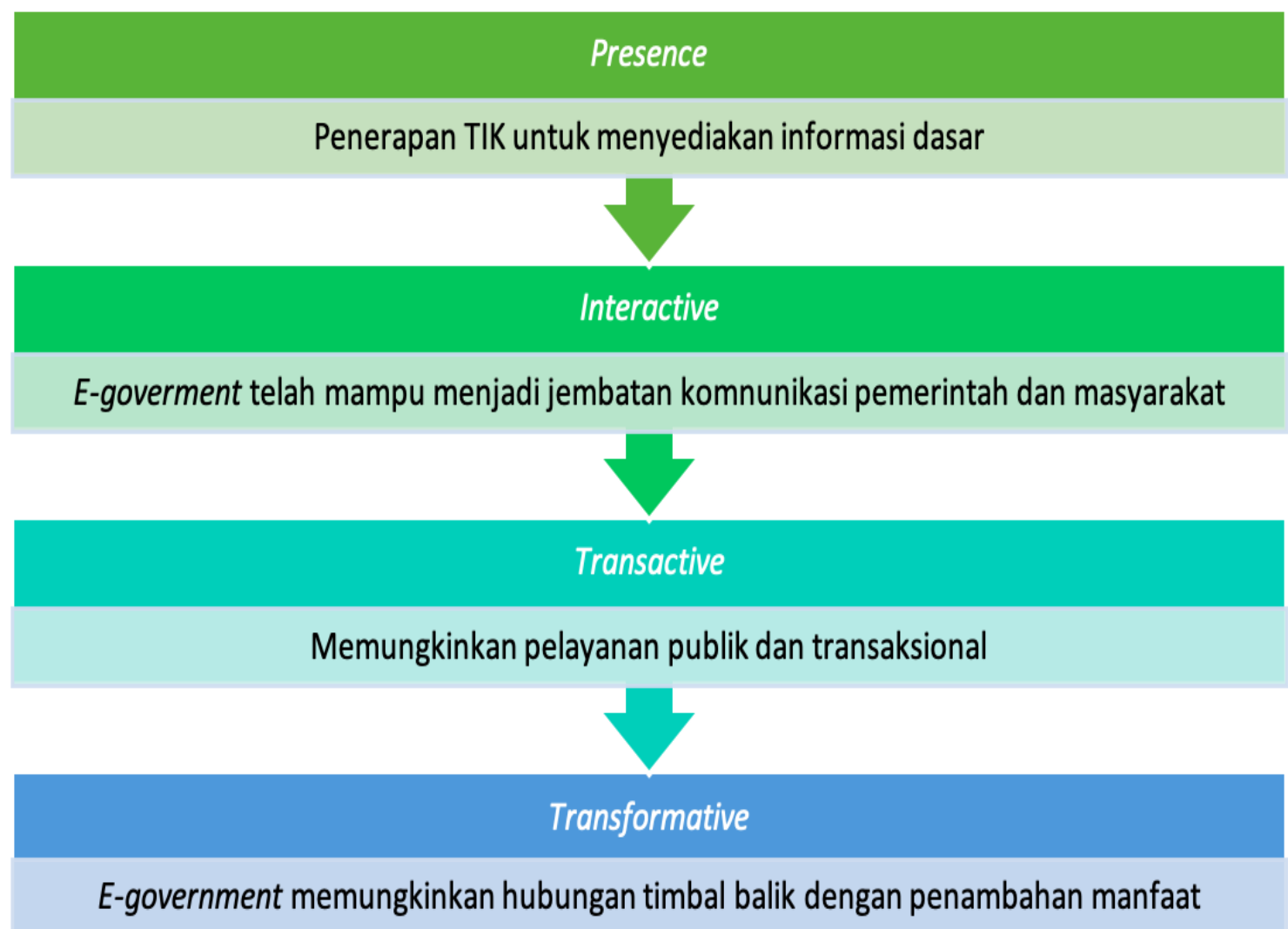

Sumber: Hasil Pelaksanaan (2021)

Gambar 1. Model kematangan e-government 
Dari tahapan kematangan Gambar 1 tampak bahwa tahapan pertama ditandai dengan adanya teknologi yang diterapkan untuk penyediaan informasi dasar. Hal ini dapat berupa pemanfaatan situs web dari instansi atau lembaga pemerintah untuk menyampaikan program pemerintah, berita kependudukan, dan sebagainya. Setelah memenuhi tahapan pertama (presence) keberadaan e-government selanjutnya diarahkan ke tahap kedua, yaitu sebagai media yang menghubungkan komunikasi antara pemerintah dengan masyarakat. Pada tahap ini, masyarakat diberikan fasilitas untuk dapat menyampaikan tanggapan atau keluhan yang dapat dilakukan secara online (terbentuknya tahap interactive).

Setelah mampu menyelesaikan tahap pertama dan kedua, diharapkan e-government juga mampu memfasilitasi masyarakat untuk mendapatkan pelayanan publik secara online dan dilengkapi dengan layanan pembayaran (transaksional) yang lebih fleksibel. Tahapan tersebut menunjukkan bahwa e-government telah mencapai tahap transactive, Lebih jauh lagi, egovernment diharapkan mencapai tahapan optimal (transformative) dimana terdapat hubungan timbal balik atau feedback yang memiliki manfaat lebih baik bagi masyarakat maupun pemerintah (Kumar, Baishya, Sadarangani \& Samalia, 2020). Tahapan kematangan ini memungkinkan terciptanya pelayanan yang berorientasi kepada masyarakat, pemerintahan yang responsif dan meningkatnya kepercayaan publik.

Pemerintah Daerah Kabupaten Pandeglang bekerjasama dengan Diskomsantik (Dinas Komunikasi, Informatika, Sandi dan Statistik) Kabupaten Pandeglang yang merupakan mitra dalam kegiatan pengabdian kepada masyarakat ini, telah berupaya secara proaktif menyediakan informasi dengan memanfaatkan teknologi berupa website resmi Kabupaten Pandeglang (https://pandeglangkab.go.id). Website tersebut bertujuan untuk membantu pemerintah daerah setempat dalam mewujudkan diseminasi untuk mengurangi kesenjangan informasi yang dialami oleh masyarakat. Melalui upaya penyediaan informasi yang berkualitas dalam situs web tersebut, selanjutnya diharapkan agar masyarakat Kabupaten Pandeglang dapat terdorong untuk mempergunakan teknolgi internet secara positif dalam rangka mengakses informasi yang dibutuhkan.

Mempertimbangkan latar belakang kondisi mitra di atas, kegiatan pengabdian kepada masyarakat yang dilaksanakan oleh tim dosen dari Fakultas IImu Komputer UPN Veteran Jakarta bertujuan untuk mengoptimalkan penerapan situs web pada Kabupaten Pandeglang untuk mempersiapkan kematangan penerapan e-government di tahap 1 (presence) dalam rangka menuju ke tahap 2 (interactive) di masa mendatang.

\section{Metode Pelaksanaan}

Pelaksanaan kegiatan pengabdian kepada masyarakat ( $\mathrm{PkM}$ ) berfokus pada bidang TIK dalam perspektif kualitas informasi yang dikaitkan dengan website resmi Kabupaten Pandeglang.

Website merupakan kumpulan halaman yang ada dalam sebuah domain di internet dan pembuatannya memiliki fungsi tertentu. Website terdiri atas sejumlah konten berupa teks, 
gambar, suara, animasi, video atau penggabungan satu dengan lainnya (Saad, 2020). Website yang digunakan oleh pemerintah daerah memiliki format domain khusus, yaitu karakter nama pemerintah daerah atau singkatannya diikuti dengan wilayah keberadaan instansi penyelenggara dan diakhiri dengan [dot] go [dot] id. Penamaan domain tersebut tersedia hingga level desa. Adanya website Pemerintah Daerah Kabupaten Pandeglang menunjukkan efektivitas penerapan e-government. Website seharusnya dapat dimanfaatkan masyarakat Pandeglang untuk dapat memperoleh informasi, menyampaikan aspirasi dan berinteraksi dengan pemerintahannya.

Metode pelaksanaan kegiatan PkM yang dilaksanakan oleh tim dosen Fakultas IImu Komputer di Diskomsantik Kabupaten Pandeglang adalah sebagai berikut :
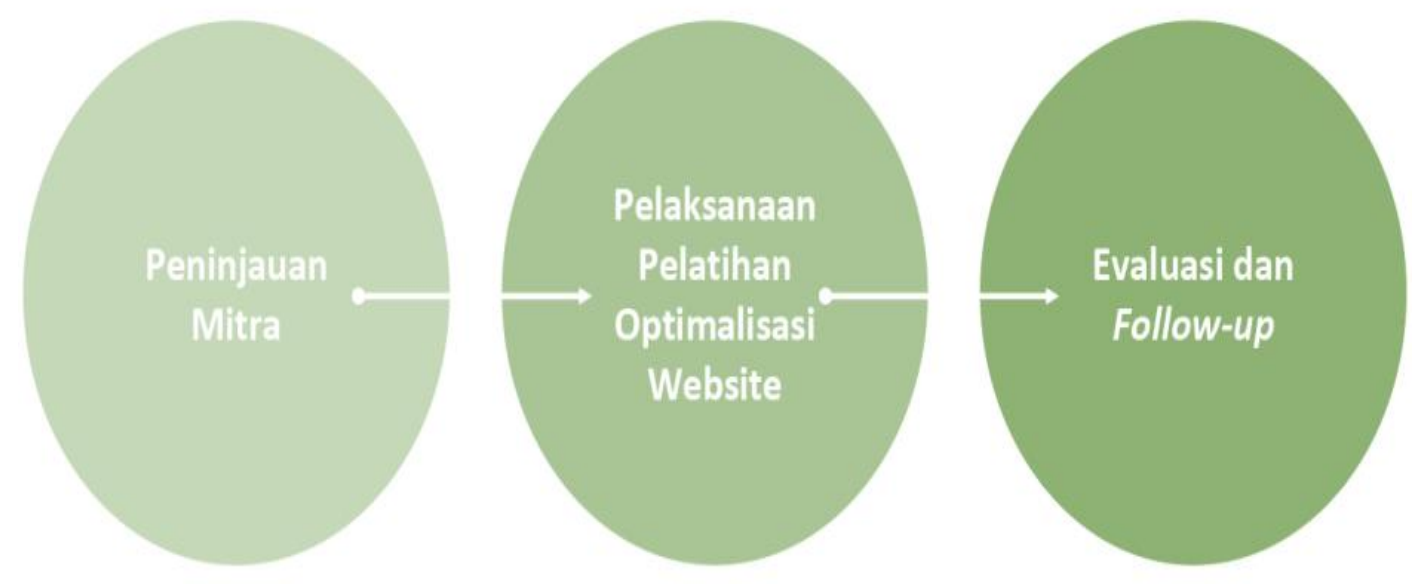

Sumber: Hasil Pelaksanaan (2020)

Gambar 2. Tahapan pelaksanaan PkM Diskomsantik Kabupaten Pandeglang

Adapun penjelasan dari masing-masing tahapan kegiatan PkM yang telah terlaksana terdiri dari peninjauan mitra, pelaksanaan pelatihan dan evaluasi peserta kegiatan.

Peninjauan mitra dilakukan mulai dari awal tahun 2020 untuk mengetahui kondisi eksisting yang dimiliki mitra khususnya dikaitkan dengan observasi terhadap penerapan teknologi yang sudah ada. Kondisi pandemi COVID-19 mengakibatkan terhambatnya proses observasi. Namun, kegiatan peninjauan mitra pada akhirnya dapat terselesaikan pada akhir bulan Juli tahun 2020.

Pelaksanaan pelatihan dilakukan selama 1 hari dan melibatkan pegawai yang berperan langsung dalam mengelola konten website. Kegiatan dibagi menjadi dua sesi, yaitu: (a) pemberian materi, dan (b) evaluasi berdasarkan kasus-kasus nyata dari website. Materi yang disampaikan secara garis besar bertemakan tentang konten website dan Search Engine Optimization (SEO) sederhana dengan modul pada gambar 3. 


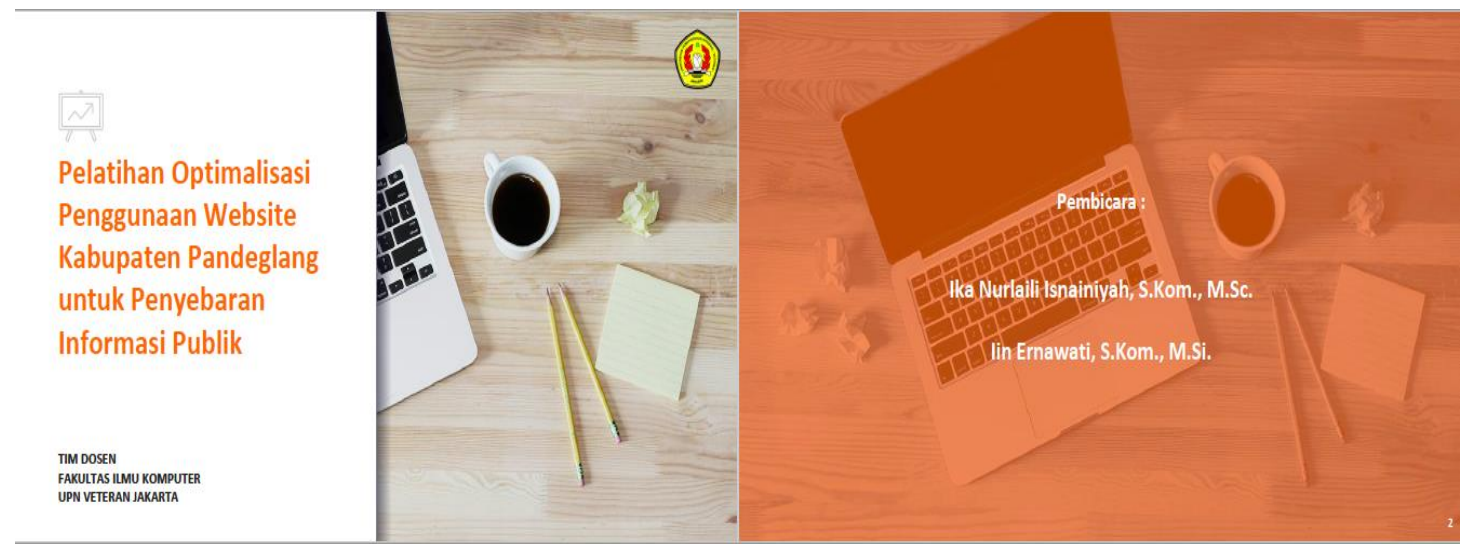

Sumber: Hasil Pelaksanaan (2020)

Gambar 3. Modul Pelatihan

Setelah mendengarkan materi, peserta kemudian dibimbing untuk mencoba melakukan identifikasi kekurangan yang ditemukan pada website Pemerintah Kabupaten Pandeglang dikaitkan dengan kematangan e-government pada tahap presence.

Peserta kegiatan diberikan evaluasi berupa kasus-kasus dan kekurangan yang dapat dioptimalkan dari website Kabupaten Pandeglang. Penilaian kasus dilakukan berdasarkan tingkat pemahaman peserta untuk mengkritisi konten yang terdapat pada website.

\section{Hasil dan Pembahasan}

Pada bagian ini, dijelaskan hasil dan pembahasan yang komprehensif dari pelaksanaan kegiatan PkM bertemakan "Pelatihan Optimalisasi Website Kabupaten Pandeglang Untuk Rakyat". Kegiatan pelatihan dilakukan di Ruang Pintar, Diskomsantik Kabupaten Pandeglang pada tanggal 7 Agustus 2020 dengan peserta sebanyak 5 pegawai pengelola (administrator dan pengembang) website Kabupaten Pandeglang.

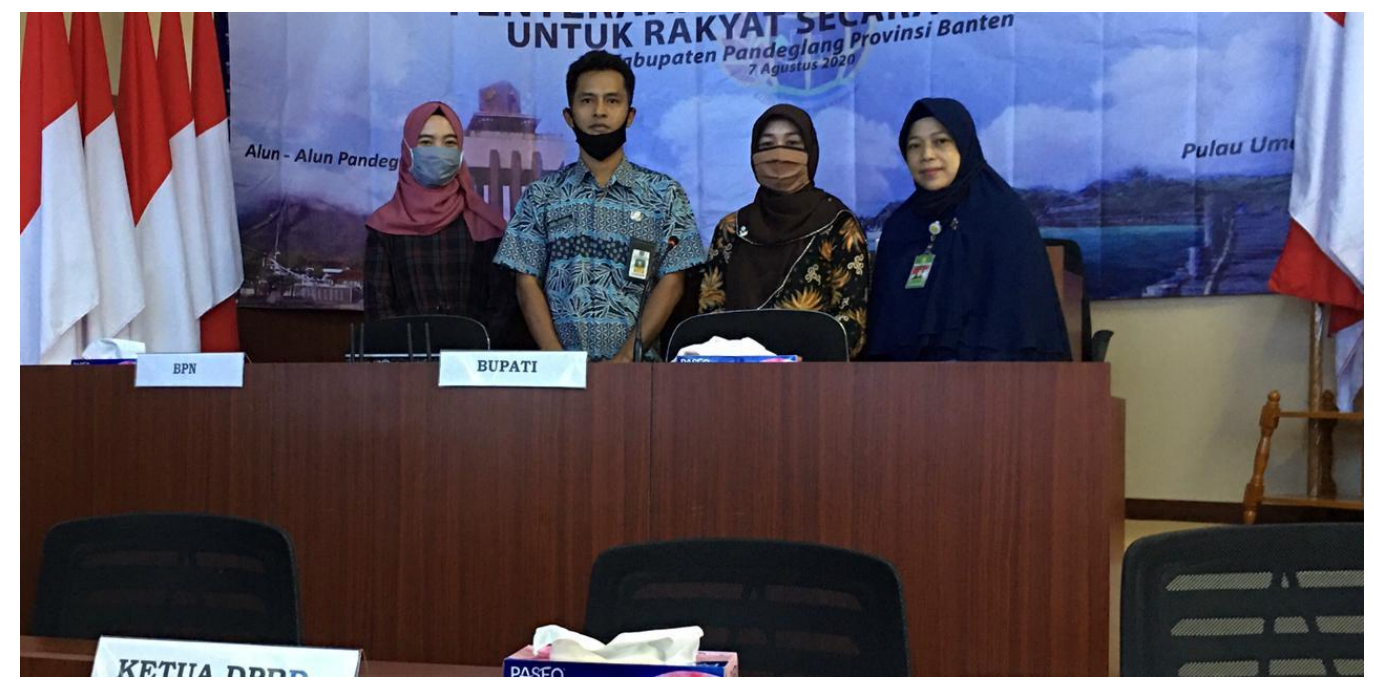

Sumber: Hasil Pelaksanaan (2020)

Gambar 4. Dokumentasi Pelaksanaan Kegiatan PkM 
Tampilan beranda dari halaman website Pemerintah Daerah Kabupaten Pandeglang (https://pandeglangkab.go.id) dapat dilhat pada gambar 5. Dalam kegiatan pelatihan ini, website diakses oleh peserta menggunakan komputer yang telah tersedia. Situs web tersebut menampilkan profil instansi, berita-berita terkini yang perlu diketahui oleh masyarakat, fasilitas yang ada di wilayah kabupaten, pilihan fitur chat, serta informasi kontak seperti alamat, e-mail dan nomor telepon instansi hingga social media yang terkait.

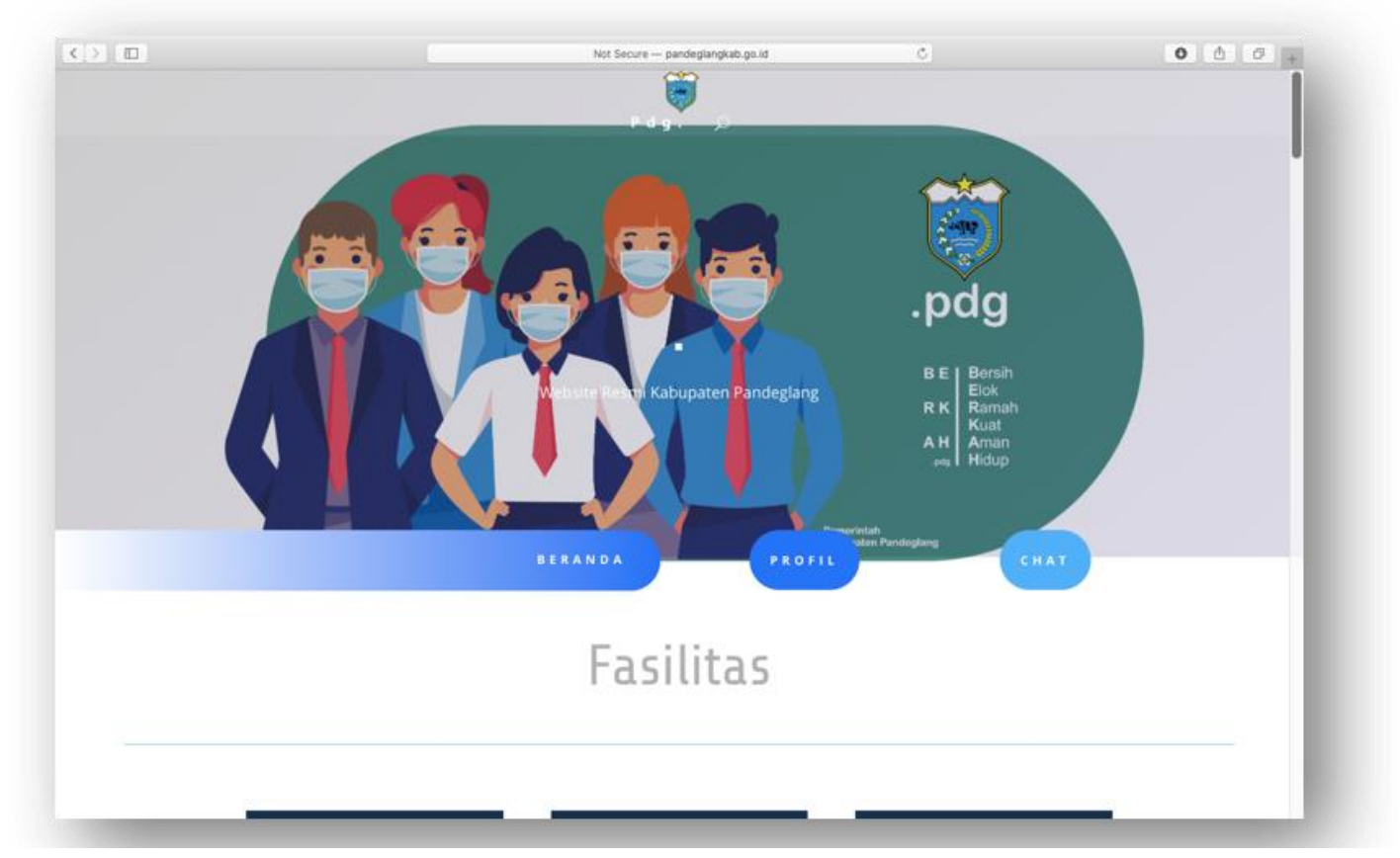

Sumber: Hasil Pelaksanaan (2020)

Gambar 5. Tampilan Beranda Website

\subsection{Evaluasi Peserta Pelatihan}

Untuk menjamin tercapainya target pengabdian masyarakat perlu dilakukan perencanaan serta evaluasi secara berkesinambungan. Kegiatan PkM ini mentargetkan adanya peningkatan pengetahuan masyarakat, dalam hal ini adalah pengelola website Kabupaten Pandeglang untuk dapat mengoptimalkan konten yang dapat menjadi bahan konsumsi publik. Konten yang baik akan memberikan pemahaman yang baik dan menyeluruh bagi masyarakat sehingga dapat meminimalisir tersebarnya berita bohong (hoax) atau hal-hal lain yang memiliki dampak negatif.

Evaluasi bagi para peserta pelatihan dilakukan sebanyak dua kali, yaitu: (a) pre-test sebelum diberikan materi, dan (b) post-test setelah peserta menerima materi. Penilaian pemahaman peserta dilakukan dengan skala penilaian 10-100 dengan kriteria nilai 10-30 pemahaman sangat kurang, nilai 31-49 pemahaman kurang namun masih mengetahui perihal prioritas konten, nilai 50-69 pemahaman cukup, nilai 70-80 pemahaman baik dan memerlukan sedikit saran tambahan dan nilai 81-100 pemahaman sangat baik dan menguasai optimalisasi konten. 
Masing-masing peserta diberikan sebanyak 5 pertanyaan untuk pre-test dan post-test yang terangkum dalam tabel 1 berikut. Peserta dapat memberikan jawaban berupa hasil analisis terhadap konten yang ditampilkan.

Tabel 1. Lembar Pertanyaan dan Evaluasi Penilaian Peserta
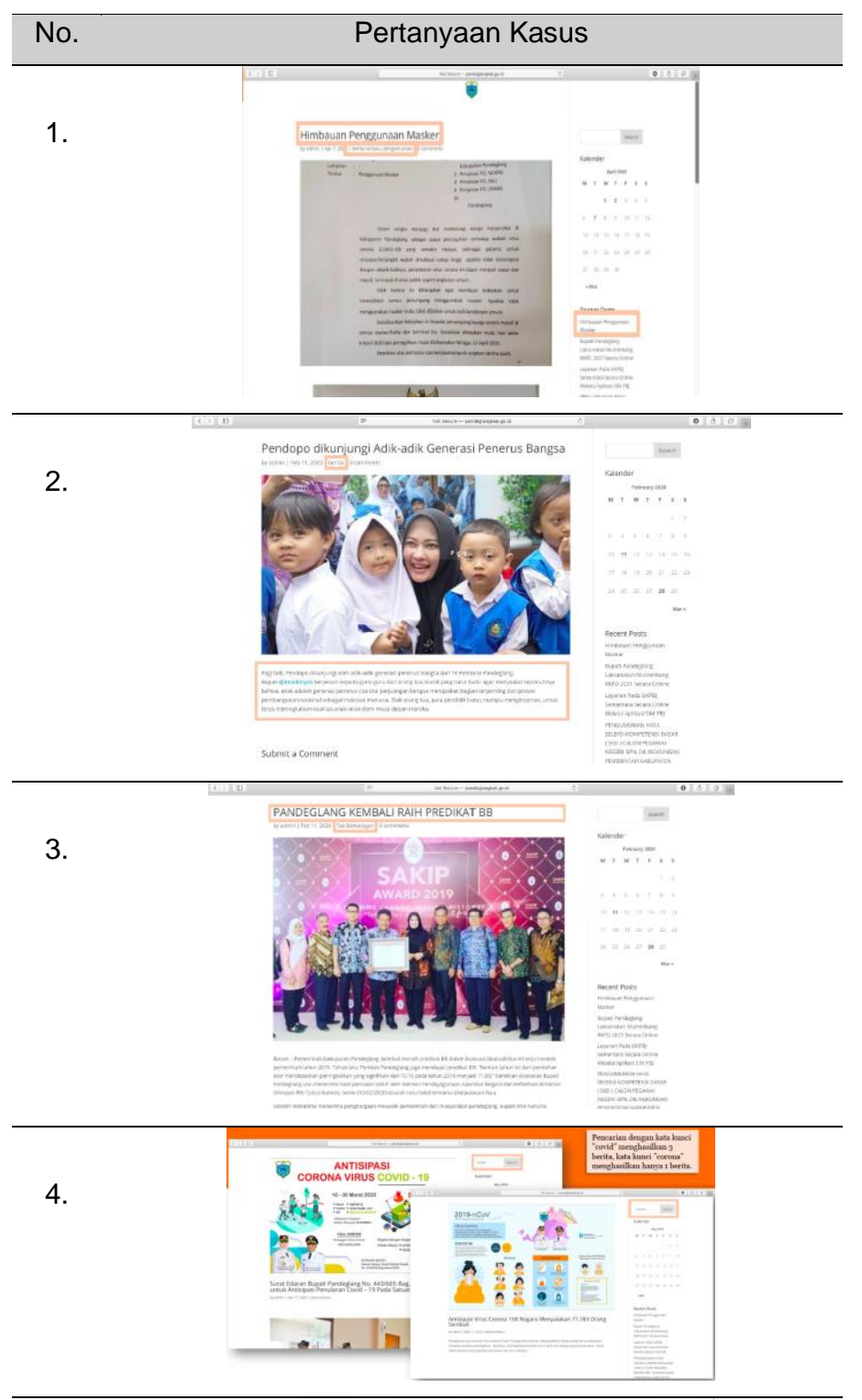

5.

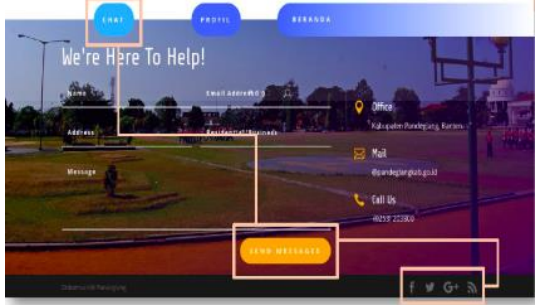

Sumber: Hasil Pelaksanaan (2020)

Lembar penilaian yang terdapat pada tabel 1 akan diisi dengan hasil analisis yang dilakukan oleh masing-masing peserta. Penilaian selanjutnya dilakukan oleh tim pelaksana PkM untuk mengevaluasi ketercapaian target pelatihan. 


\subsection{Hasil Evaluasi}

Setelah seluruh peserta selesai memberikan hasil analisis terhadap 5 kasus yang diberikan, tim akan melakukan rekapitulasi hasil penilaian dan disajikan dalam tabel 2 berikut.

Tabel 2. Total Hasil Penilaian Peserta

\begin{tabular}{ccc}
\hline Peserta ke- & \multicolumn{2}{c}{ Total Nilai } \\
\cline { 2 - 3 } & Pre-test & Post-test \\
\hline 1 & 65 & 80 \\
\hline 2 & 72 & 90 \\
\hline 3 & 66 & 82 \\
\hline 4 & 68 & 85 \\
\hline 5 & 66 & 81 \\
\hline
\end{tabular}

Sumber: Hasil Pelaksanaan (2020)

Berikut gambaran grafik penilaian peserta terhadap penilaian pre-test dan post-test.

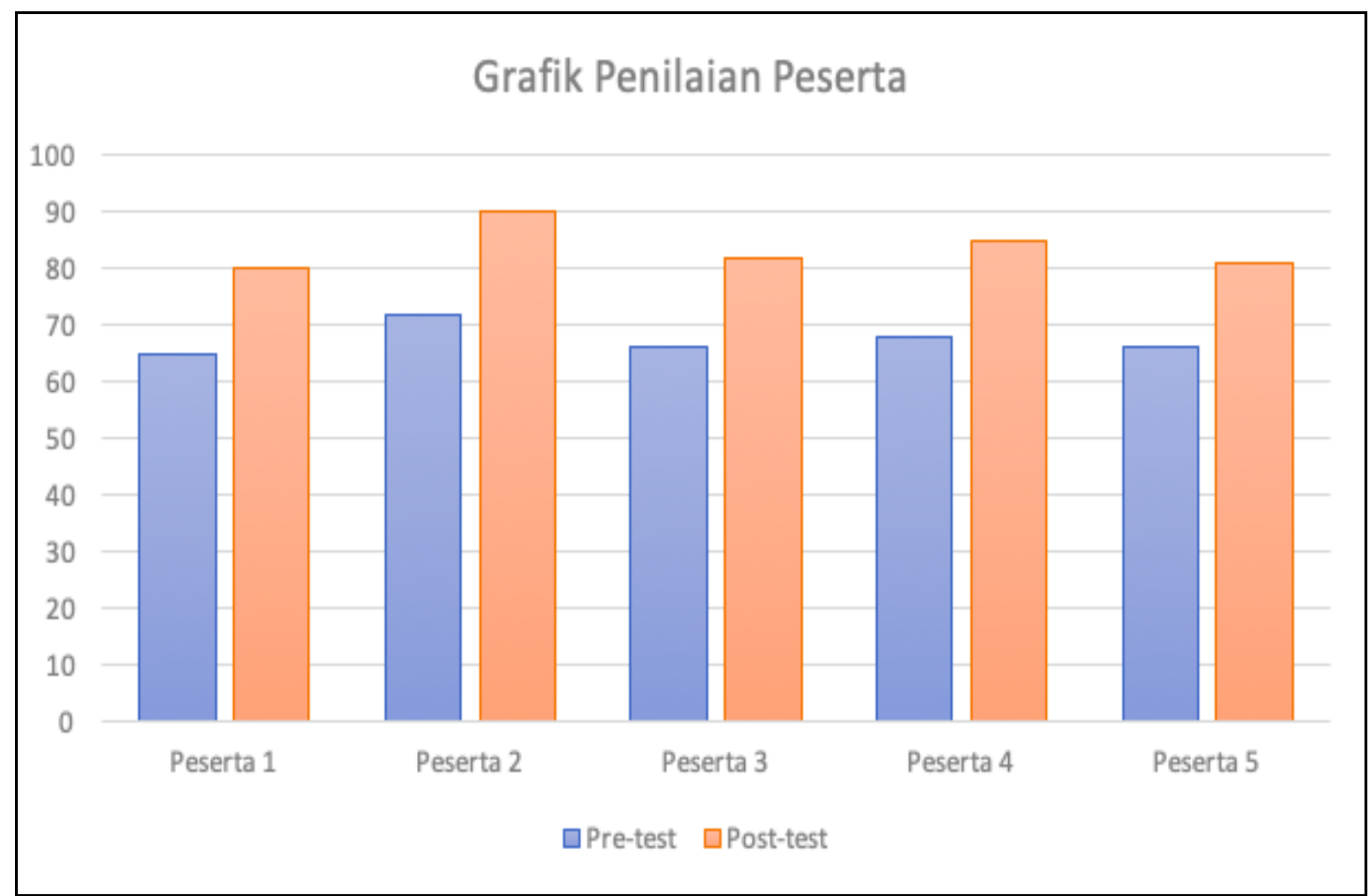

Sumber: Hasil Pelaksanaan (2020)

Gambar 6. Visualisasi Hasil Penilaian Peserta

Gambar 6 menampilkan visualisasi penilaian yang diperoleh oleh seluruh peserta pelatihan. Berdasarkan grafik, diketahui bahwa peserta memperoleh tambahan pengetahuan setelah mengikuti kegiatan pelatihan yang dibuktikan dengan kenaikan perolehan skor penilaian. Melalui hasil perhitungan statistik deskriptif (Khotimah \& Nasrulloh, 2021), diketahui bahwa rata-rata nilai pre-test peserta $\left(n \_a v g_{1}\right)$ adalah $67,4\left(n \_\max _{1}=72\right)$ dan rata-rata nilai post-test $\left(n \_a v g_{2}\right)$ adalah 83,6 $\left(n \_\max _{2}=90\right)$. Hal tersebut menunjukkan bahwa pengetahuan peserta mengalami kenaikan sebesar $24 \%$ dari nilai rata-rata awal sebelum dilakukan pelatihan pada kegiatan PkM. 


\section{Kesimpulan}

Kegiatan PkM bertajuk "Pelatihan Optimalisasi Website Kabupaten Pandeglang Untuk Rakyat" telah dilaksanakan kepada peserta dari Diskomsantik Kabupaten Pandeglang. Kegiatan pelatihan dibagi menjadi dua sesi, yaitu pemberian materi serta evaluasi berdasarkan kasus-kasus nyata dari website (https://pandeglangkab.go.id). Materi yang disampaikan secara garis besar bertemakan tentang cara-cara melakukan optimaliasi konten website dan SEO sederhana untuk meningkatkan traffic serta kemudahan pencarian informasi. Kegiatan PkM telah memenuhi target yang diharapkan, yaitu adanya peningkatan pengetahuan sebesar $24 \%$ dari para peserta pelatihan. Hal tersebut menjadi sebuah parameter kematangan penerapan egovernment pada tahap presence menuju ke tahap interactive.

\section{Ucapan Terima Kasih}

Penulis mengucapkan terima kasih kepada Lembaga Penelitian dan Pengabdian Masyarakat (LPPM) Universitas Pembangunan Nasional Veteran Jakarta sebagai penyandang dana kegiatan PkM serta pihak Diskomsantik Kabupaten Pandeglang selaku mitra dalam kegiatan ini.

\section{Daftar Pustaka}

Cahyana, R., \& Zakariya, M. I. (2016). Pengembangan Papan Informasi Digital untuk Menyiarkan Ulang Informasi yang Diterbitkan pada Situs Web. Jurnal Algoritma, 13(2), 281-286.

Kamaliah, K. (2015). Implementasi Undang-Undang Nomor 14 Tahun 2008 Tentang Keterbukaan Informasi Publik Di Badan Perencanaan Pembangunan Daerah Kota Samarinda. eJournal IImu Pemerintahan, 3(2), 1113-1125.

Khotimah, K., \& Nasrulloh, M. F. (2021). Statistik Deskriptif. LPPM Universitas KH. A. Wahab Hasbullah.

Kumar, S., Baishya, K., Sadarangani, P. H., \& Samalia, H. V. (2020). Cultural influence on egovernment development. Electronic Journal of Information Systems Evaluation, 23(1), 17-33.

Lusta, A. A. B., \& Aktas, Y. (2017). The Five Models for E-Government. Imperial Journal of Interdisciplinary Research, 3(2).

Saad, M. I. (2020). Otodidak Web Programming: Membuat Website Edutainment. Elex Media Komputindo.

Sinaga, E., Suwitri, S., \& Mustam, M. (2014). Implementasi Instruksi Presiden No. 3 tahun 2003 Tentang Kebijakan dan Strategi Nasional Pengembangan Electronic Government Di Kabupaten Semarang. Journal of Public Policy and Management Review, 3(4), 202-210.

Wiratmo, L. B., Irfan, N., \& Kuwatono, K. (2017). Website Pemerintah Daerah sebagai Sarana Online Public Relations. Jurnal Aspikom, 3(2), 326-339. 
Yunita, N. P., \& Aprianto, R. D. (2018). Kondisi Terkini Perkembangan Pelaksanaan EGovernment di Indonesia: Analisis Website. Prosiding Seminar Nasional Teknologi Informasi dan Komunikasi, 329-336. 